\title{
Evaluation of Starch Components, Pasting and Functional Properties of PleurotusTuberregium Flour from Air Dried Sclerotia
}

\author{
Amaechi, N.C \\ Okoronkwo, C.U ${ }^{2}$ \\ Agbaeze, $T^{3}$ (D)
}

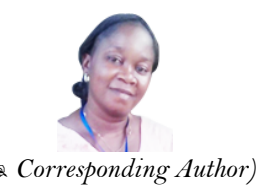

( Corresponding Author)

${ }^{2.2 .}$ Department of Food Science and Technology, Abia State University, Uturu-Abia State, Nigeria. 'Email: chinonyeremrvog@yahoo.com Tel: 08051710488

Email:okoronkwoochristopher95@yahoo.com Tel: 08036260891

'Email: tecy4love@yahoo.com Tel: 07038988365

\section{Abstract}

Pleurotus tuberregium is one group of mushroom that produce edible sclerotia and is used for various culinary and medicinal purposes. Flour was produced from the air dried sclerotia and starch components, pasting and functional properties were evaluated. It had a total and resistant starch contents of $73.63 \%$ and $12.37 \%$ respectively while its amylose content was $20.03 \%$. Its amylose and resistant starch contents classified it as regular and high resistant starch flour. Its pasting properties revealed it had pasting temperature and peak time of $60.16^{\circ} \mathrm{C}$ and $5.97 \mathrm{~min}$ respectively. Results on breakdown viscosity, set back viscosity and set back ratio revealed a high tendency of the flour to retrograde after gelatinization and when shear stress is applied. It had low swelling capacity, moderate dispersibility index and high gelatinization temperature with values of $4.17 \mathrm{~g} / \mathrm{g}, 53 \%$ and $94^{\circ} \mathrm{C}$ respectively. This therefore suggests that flour from air dried Pleurotus tuberregium sclerotia can be utilized in food formulations where high resistant starch is relevant for nutritional purposes and as thickeners in food products. However, there is need for technological modification to improve its pasting properties so as to generate flour with a high stability ratio and a low set back ratio and so withstand retrogradation and with improved resistance to shear stress.

Keywords: Pleurotus tuberregium sclerotia, Air-dried flour, Resistant starch, Pasting properties, Dispersibilty index, Amylose, Amylopectin, Set back ratio, Stability ratio, Gelatinization temperature.

Citation | Amaechi, N.C; Okoronkwo, C.U; Agbaeze, T (2020) Evaluation of Starch Components, Pasting and Functional Properties of PleurotusTuberregium Flour from Air Dried Sclerotia. Agriculture and Food Sciences Research, 7(2): 31-38. History:

Received: 15 September 2020

Revised: 12 October 2020

Accepted: 29 October 2020

Published: 18 November 2020

Licensed: This work is licensed under a Creative Commons

Attribution 3.0 License (cc)

Publisher: Asian Online Journal Publishing Group
Acknowledgement: All authors contributed to the conception and design of the study.

Funding: This study received no specific financial support.

Competing Interests: The authors declare that they have no conflict of interests.

Transparency: The authors confirm that the manuscript is an honest, accurate, and transparent account of the study was reported; that no vital features of the study have been omitted; and that any discrepancies from the study as planned have been explained.

Ethical: This study follows all ethical practices during writing.

\section{Contents}

1. Introduction

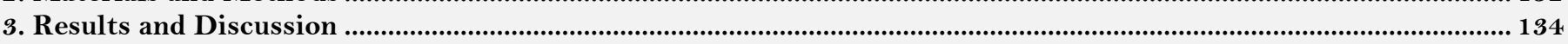

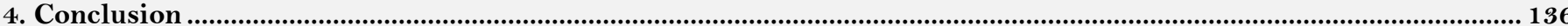

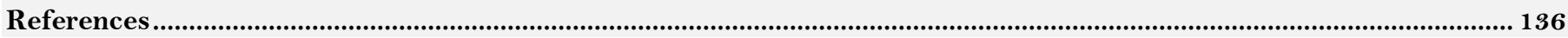




\section{Contribution of this paper to the literature}

This study has provided information on the nutritional, technological usefulness and functionality of flour from air dried Pleurotus tuberregium sclerotia. The research has shown that flour from air dried sclerotia has resistant starch but there is need for technological modification to improve its pasting properties.

\section{Introduction}

Edible mushrooms form part of diet in many human populations because of their unique flavour, texture or for their nutritional benefits such as having antioxidant activity. Some mushroom species produce sclerotia which are edible and used for various purposes. The search for new food ingredients with good functionality and nutritional value has resulted to the exploitation of mushrooms and has been of interest to food technologists lately. The utilization of mushroom flours is limited due to absence of knowledge about their functional and compositional characteristics and their interactions [1]. Pleurotus tuberregiumis a tropical edible mushroom that produces edible sclerotium/underground tuber as well as mushroom [2]. The sclerotium of Pleurotus tuberregium is a compact mass of hardened mycelium containing food reserves which help the fungi survive environmental extremes [3]. It is highly nutritious containing good quality protein and carbohydrate with little fat [4].

Major reserve carbohydrates in foods is starch comprised of polymer units namely amylose and amylopectin. The relative proportion of amylose and amylopectin and their organization within starch granules determine the functional properties of the starch and consequently its range of industrial applications in foods, pharmaceuticals etc [5]. Starch contributes to textural properties of many foods and is commonly used in food and industrial applications as thickener, stabilizer and gelling agent [6]. Pasting properties are functional properties associated with the ability of an item to act in paste-like manner [7]. Dietary starches are important sources of energy for humans which during digestion, a portion goes undigested in the upper gastrointestinal tract and so is referred to as resistant starch. Lately, there is a lot of interest in resistant starch for its potential health benefits as is to soluble fibre as well as its functional properties [8]. The physical properties of resistant starch makes it a functional ingredient that provides good handling and improve texture in the final product [9].

Mushrooms have the ability to develop a morphological form known as sclerotium which is a compact mycelia structure under unfavorable conditions and can remain dormant until there is suitable environmental conditions required for fruiting bodies germination [10]. This mycelia structure known as the sclerotia serve as food reserve for fruiting bodies and is consumed as food by man. It is in view of this that starch components, pasting and functional properties of flour produced from air dried Pleurotus tuberregium sclerotia was evaluated. This will provide information about its usefulness in food formulation and its functional characteristics as a healthy food ingredient.

\section{Materials and Methods}

\subsection{Sclerotia Collection and Preparation of Flour Sample}

Pleurotus tuberregium sclerotia was purchased from a local market in Umuahia, Abia State, Nigeria. The outer dirty brown back was peeled using stainless steel knife while the inner white mass of sclerotia was cut in small pieces of $5 \mathrm{~mm}$ thickness and air dried on stainless tray in the laboratory (room temperature $25 \pm 2^{\circ} \mathrm{C}$ ). The air dried sclerotia was milled using a blender (Master Chef, India) at speed No2 into fine flour and was packaged in an airtight container and stored at room temperature prior to analysis.

\subsection{Analysis of Starch Components.}

2.2.1 Determination of Total Starch:

Total starch was determined by the AOAC method 996.11 described by Mccleary, et al. [11]. 50g of the flour was passed through a $0.5 \mathrm{~mm}$ screen and $100 \mathrm{mg}$ of the sieved flour was weighed into a glass centrifuge. The tube was tapped to ensure all the samples falls to the bottom of the tube before $0.2 \mathrm{mi}$ ethanol $(80 \% \mathrm{v} / \mathrm{v})$ was added and the contents were stirred on a vortex mixer before $2 \mathrm{ml}$ dimethylsulphoxide was added and stirred continuously on the vortex mixer for $3 \mathrm{~min}$. Subsequently the tube with its contents were placed in a vigorously boiling water bath for $5 \mathrm{~min}$. Immediately3ml of thermostable $\alpha$-amylase was added and the tube was incubated in a boiling water bath for $6 \mathrm{~min}$ with intermediate vigorous stirring after 2,4 , and $6 \mathrm{~min}$ to ensure homogeneity. After which, the tubes were placed in a water bath at $50^{\circ} \mathrm{C}$ and $0.1 \mathrm{ml}$ amyloglucosidase suspension was added to the mixture and the contents were stirred on a vortex mixer and incubated at $50^{\circ} \mathrm{C}$ for $30 \mathrm{~min}$. After this step, the contents were transferred to a $100 \mathrm{ml}$ volumetric flask and distilled water was used to rinse tube contents thoroughly and the volume was adjusted to $10 \mathrm{ml}$ and mixed thoroughly before centrifuging at $3000 \mathrm{rpm}$ for $10 \mathrm{~min}$. $1 \mathrm{ml}$ of the supernatant was diluted to $10 \mathrm{ml}$ with distilled water. A reagent blank, glucose standard and test sample were subjected to endpoint analysis using GOD-PAP reagent. For the test sample, $0.1 \mathrm{ml}$ of diluted supernatant was dispensed into a test tube and $3 \mathrm{ml}$ GOD-PAP reagent was added, the blank contained $3 \mathrm{ml}$ GOD-PAP reagent and $0.1, \mathrm{~m}$ water while the standard contained $3 \mathrm{ml}$ GOD-PAP reagent plus $0.1 \mathrm{ml}$ glucose standard. All these were incubated at $50^{\circ} \mathrm{C}$ for $20 \mathrm{~min}$ and absorbance were read at $510 \mathrm{~nm}$ against the reagent blank. Total starch was calculated as shown in Equation 1:

$$
\text { Starch }(\%)=\Delta \mathrm{A} \times \frac{\mathrm{F}}{\mathrm{W}} \mathrm{X} F \mathrm{X} 0.9
$$

$\Delta A$ is sample GOD-PAP absorbance read against reagent blank.

$\mathrm{F}$ is the factor used to convert from absorbance to $\mu \mathrm{g}$ of glucose.

$\mathrm{W}$ is weight of sample analysed in $\mathrm{mg}$.

$\mathrm{FV}$ is final volume of solution used.

\subsubsection{Determination of Amylose and Amylopectin}

Amylose was determined by the iodine colorimetric method described by Mohana, et al. [12]. The flour sample was defatted prior to analysis.100mg of the defatted flour was weighed into $100 \mathrm{ml}$ volumetric flask to which $1 \mathrm{ml}$ 
95\% ethanol and 9ml $1 \mathrm{~N} \mathrm{NaOH}$ were added and mixed thoroughly. After which it was heated on boiling water bath to gelatinize the starch and later on cooled to room temperature. $5 \mathrm{ml}$ of the gelatinized starch solution was dispensed into a $100 \mathrm{ml}$ volumetric flask to which $1 \mathrm{ml}$ of $1 \mathrm{~N}$ acetic acid and $2 \mathrm{ml}$ of iodine solution were added and the volume made up to $100 \mathrm{ml}$ with distilled water. All the contents were thoroughlyvortexed mixed and allowed to stand for 20mins. The absorbance was measured at 620nm in a spectrophotometer using a blank containing $5 \mathrm{ml}$ 0.09N NaOH, $1 \mathrm{ml}$ acetic acid and $2 \mathrm{ml}$ iodine solution and made up to $100 \mathrm{ml}$ volume using distilled water. The amylose content was determined based on the standard curve prepared using potato amylose. Amylopectin was calculated by difference stated by Juan, et al. [13] shown in Equation 2:

$$
\text { Amylopectin }(\%)=100-\text { Amylose (\%) }
$$

\subsubsection{Evaluation of Resistant Starch}

Resistant starch was evaluated by the method described by Goñi, et al. [14]. 100mg of the sample was dispensed into centrifuge tube and $10 \mathrm{ml} \mathrm{KCl-HCl}$ buffer ( $\mathrm{pH} 1.5$ ) was added and the mixture homogenized. $0.2 \mathrm{ml}$ pepsin was added to the homogenized sample mixture and incubated at $40^{\circ} \mathrm{C}$ for $60 \mathrm{~min}$ with constant shaking in a water bath. After which the sample was cooled to room temperature, $9 \mathrm{ml}$ Tris -maleate buffer $(\mathrm{pH} 6.9)$ was added alongside $1 \mathrm{ml} \alpha$-amylase was added to the mixture, shaken well and incubated for $16 \mathrm{~h}$ at $37^{\circ} \mathrm{C}$ in a water bath with constant shaking. Subsequently the sample was centrifuged for $15 \mathrm{~min}$ at $3000 \mathrm{rpm}$ and the supernatant was discarded leaving the sediment. The sediment was washed once with $10 \mathrm{ml}$ distilled water, centrifuged and the supernatant discarded before adding $3 \mathrm{ml}$ distilled water and $3 \mathrm{ml} 4 \mathrm{M} \mathrm{KOH}$. The contents were mixed thoroughly and left to stand at room temperature for $30 \mathrm{~min}$ with constant shaking before $5 \mathrm{ml}$ buffer $(\mathrm{pH} 4.75)$ and $0.08 \mathrm{ml}$ amyloglucosidase were added and mixed. The sample mixture was incubated for $45 \mathrm{~min}$ at $60^{\circ} \mathrm{C}$ in a water bath with constant shaking. The mixture was clarified by centrifuging at 3000rpm for $15 \mathrm{~min}$ and the supernatant siphoned into a volumetric flask. The residue was washed twice with $10 \mathrm{ml}$ distilled water and clarified by centrifuging each time and the supernatant recovered and combined with was put into the volumetric flask previously. The recovered supernatant solution was made up to $100 \mathrm{ml}$ using distilled water. A standard curve containing 10-60ppm glucose was generated. $0.5 \mathrm{ml}$ water, sample and standard glucose solutions were dispensed into test tubes. $1 \mathrm{ml} \mathrm{GOD-PAP}$ was added to each to each test tube and incubation was done for $30 \mathrm{~min}$ at $37^{\circ} \mathrm{C}$ in a water bath. Absorbance of test and standards were read at 500nm against reagent blank. The standard curve was used to calculated glucose concentration of the sample. Resistant starch was calculated as shown in Equation 3:

$$
\text { Resistant starch (\%) = mg of glucose X } 0.9
$$

\subsection{Pasting Properties Determination}

Pasting properties of Pleurotustuberregiumsclerotia flour was evaluated using Rapid ViscoAnalyser (Dingling RVU 232015, USA) by methods described by AACC [15]. A $3 \mathrm{~g}$ sample was dispersed in an aluminium canister containing $25 \mathrm{ml}$ of distilled water. The sample mixture underwent a controlled heating and cooling cycle under constant shear where it was held at $50^{\circ} \mathrm{C}$ for $1 \mathrm{~min}$, heated from 50 to $95^{\circ} \mathrm{C}$ at $6{ }^{\circ} \mathrm{C} / \mathrm{min}$ and held at $95^{\circ} \mathrm{C}$ for $5 \mathrm{~min}$. Finally each sample was cooled to $50^{\circ} \mathrm{C}$ and held for another $2 \mathrm{~min}$. The starch viscosity parameters measured were peak viscosity $(\mathrm{PV})$, trough viscosity viscosity at the end of holding time at $95^{\circ} \mathrm{C}(\mathrm{HPV})$, breakdown viscosity (PV$\mathrm{HPV})$, cool paste viscosity (CPU) final viscosity-viscosity at the end of the hold time at $50^{\circ} \mathrm{C}$; setback viscosity $(\mathrm{SBV}) \sim(\mathrm{CPU}-\mathrm{HPV})$, pasting time $=$ time from onset of pasting to peak viscosity, pasting temperature $=$ temperature from onset of pasting to peak viscosity. Stability ratio $(\mathrm{SR})=\frac{H P V}{P V}$ and setback ratio $(\mathrm{SBR})=\frac{C P V}{H P V}$ were calculated prescribed by Julianti, et al. [16].

\subsection{Functional Properties Determination \\ 2.4.1 Bulk Density}

Bulk density was determined by the method described by Onabanjo and Ighere [17]. A 50g weight of Pleurotustuberregiumsclerotia flour was put into $100 \mathrm{ml}$ measuring cylinder. The cylinder was tapped several times on a laboratory bench to a constant volume. The volume of sample was calculated as shown in Equation 4:

Bulk density $\left(\mathrm{g} / \mathrm{cm}^{3}\right)=\frac{\text { Weight of sample }}{\text { Volume of sample after tapping }}$

\subsubsection{Water Absorption Capacity (WAC) and Oil Absorption Capacity (OAC)}

These were determined by the methods described by Onabanjo and Ighere [17]. For WAC, $1 \mathrm{~g}$ of Pleurotustuberregiumsclerotia flour was dispensed into $25 \mathrm{ml}$ centrifuge tube and $15 \mathrm{ml}$ distilled water was added to it and the tube was agitated on a vortex mixer for $2 \mathrm{~min}$. The suspension was centrifuged at $1000 \mathrm{rpm}$ for $20 \mathrm{~min}$ and after which, the clear supernatant was decanted and discarded. The wet flour residue was reweighed and water absorption was expressed as weight of water bound by $100 \mathrm{~g}$ dried flour. The same procedure was used for oil absorption capacity except that water was replaced with vegetable oil of specific gravity of $0.98 \mathrm{~g} / \mathrm{ml}$. Water absorption capacity and oil absorption capacity were expressed as shown in Equation 5:

$W A C / O A C(g / g)=\frac{\text { Weight of sediment }}{\text { Initial weight of flour }}$

\subsubsection{Emulsion Activity}

This was determined by the method described by Yasumatsu, et al. [18]. A mixture of $1 \mathrm{~g}$ flour sample, $10 \mathrm{ml}$ distilled water and $10 \mathrm{ml}$ soybean oil was prepared in a calibrated centrifuge tube. The emulsion was centrifuged at 2000rpm for 5min. The ratio of the height of emulsion layer to the total height of the mixture was calculated as emulsion activity in percentage shown in Equation 6:

Emulsion activity $(\%)=\frac{\text { Height of emulsion layer before centrifugation }}{\text { Total height of the mixture after centrifugation }} \times \frac{100}{1}$. 


\subsubsection{Emulsion Stability}

This was determined by the method of Yasumatsu, et al. [18]. Emulsion stability was estimated after heating the emulsion in the calibrated centrifuge tube which was obtained from the determination of emulsion activity at $80^{\circ} \mathrm{C}$ for $30 \mathrm{~min}$ in a water bath. This was followed up by cooling for 15 mins under running tap water and centrifuged at 2000rpm for 15min. Emulsion stability was expressed as shown in Equation 7:

Emulsion stability $(\%)=\frac{\text { Height of emulsified layer }}{\text { Totsl height of the mixture }} \times \frac{100}{1} \ldots$

\subsubsection{Foam Capacity and Foam Stability}

Foam capacity and foam stability were determined by the methods described by Narayana and Narasinga Rao [19]. Foam capacity was evaluated by dispensing $1 \mathrm{~g}$ flour sample into a blender and $10 \mathrm{ml}$ deionized water $(\mathrm{pH}$ adjusted to 7.4 using $1 \mathrm{~N} \mathrm{NaOH}$ and $1 \mathrm{~N} \mathrm{HCl}$ ) was added. The mixture was blended for 5 min before turning into a $250 \mathrm{ml}$ graduated cylinder and the foam volume was recorded immediately. Foam capacity was calculated as shown in Equation 8:

Foam capacity $(\%)=\frac{\text { Volume of foam after whipping }}{\text { Volume of foam before } \text { whipping }} \times \frac{100}{1} \ldots$

Foam stability: Foam stability was evaluated by recording foam volume in the cylinder $1 \mathrm{~h}$ after whipping as percent of initial foam volume, shown in Equation 9.

Foam stability $(\%)=\frac{\text { Volume of foam } 1 \text { h after whipping }}{\text { Volume of foam immediately after whipping }} \times \frac{100}{1}$.

\subsubsection{Swelling Index and Swelling Capacity}

These were analysed by the methods described by Ukpabi and Ndimele [20]. Swelling index was determined by dispensing $25 \mathrm{~g}$ of flour sample into $250 \mathrm{ml}$ measuring cylinder. $150 \mathrm{ml}$ deionized water was added and the mixture was shaken and allowed to stand for $4 \mathrm{~h}$ before observing the extent of swelling. Swelling index was calculated as shown in Equation 10:

Swelling index $(g / g)=\frac{\text { Volume after soaking }- \text { Volume before soaking }}{\text { Weight before soaking }}$...

Swelling capacity: The gel obtained after determining swelling index was used in calculating swelling capacity as shown in Equation 11:

Swelling capacity $(\mathrm{g} / \mathrm{g})=\frac{\text { Weight of gel after soaking }}{\text { Weight of sample before soaking }}$

\subsubsection{Dispersibility}

This was determined by the methods described by Kulkarni, et al. [21]. $10 \mathrm{~g}$ of flour sample was weighed into a graduated cylinder and $100 \mathrm{ml}$ distilled water was added to it. The mixture was shaken vigorously and allowed to stand for $3 \mathrm{~h}$ before the volume of settled particles was recorded.

\subsubsection{Gelatinization Temperature}

It was determined by the method described by Shinde [22]. $1 \mathrm{~g}$ flour sample was weighed into a $20 \mathrm{ml}$ screw capped tube and $10 \mathrm{ml}$ water was added to it and shaken vigorously before it was heated slowly in a water bath until a solid gel was formed. The temperature at which a gel was formed was recorded in ${ }^{\circ} \mathrm{C}$.

\section{Results and Discussion}

\subsection{Starch Components}

Resultson starch components of Pleurotus tuberregium flour from air dried sclerotia is shown in Table 1. Its total starch content of $73.63 \%$ was comparable to total starch content of Pleurotus ostreatus and had a value of $75 \%$ [23] but higher than starch from green cadaba banana flour subjected to various drying methods and had values between 29.24 and $40.77 \%$ [24] .

Its amylose and amylopectin contents were $20.03 \%$ and $53.60 \%$ respectively. The ratio of amylose and amylopectin in starch influences mechanical property of starch polymer [25]. Its amylose content (20.03\%) was comparable to amylose content of P. ostreatus(21.7\%) [23] but lower than amylose content of native banana and plantain starches which had values of $42.07 \%$ and $38.79 \%$ respectively [6]. Amylopectin content (52.62\%) observed in this work was lower than amylopectin content of P. ostreatus(78.30\%) [23]. Amylose content is the underlying condition for categorizing starches into waxy, semi-waxy, regular and high amylose types when amylose content is O-2\%, 3-15\%, 15-35\% and $>40 \%$ of the total starch respectively [26]. In the current study, starch from air dried Pleurotustuberregium flour can be classified as regular starch.

Resistant starch content observed for P. tuberregiumwas $12.37 \%$. This value was lower than resistant starch content of green Cadaba banana flour subjected to different drying methods with values that ranged between 16.83 and $27.53 \%$ [22] but higher than resistant starch content of different cassava varieties which ranged between 1.12 and $4.14 \%$ reported by Chisenga, et al. [27]. Goñi, et al. [14] classified food materials with resistant starch content of $5-15 \%$ as high resistant starch foods. This suggests that flour from air dried sclerotia of Pleurotustuberregiumcan be classified as high resistant starch flour. Resistant starch functions physiologically as fibre in promoting a healthy gastrointestinal environment such as being a prebiotic compound [8]. Therefore, incorporation of $P$. tuberregiumflour into food formulations will be of benefit in promoting a healthy gut environment. 
Table-1.Starch fractions of Pleurotus tuberregium flour from air dried sclerotia

\begin{tabular}{l|c}
\hline Parameter & Value \\
\hline Total starch (\%) & $73.63 \pm 0.00$ \\
\hline Amylose (\%) & $20.03 \pm 0.00$ \\
\hline Amylopecyin (\%) & $53.62 \pm 0.02$ \\
\hline Resistant starch (\%) & $12.37 \pm 0.01$ \\
\hline
\end{tabular}

Note: Values are means \pm standard deviation.

\subsection{Pasting Properties}

Table 2 shows results on pasting properties of flour from air dried $P$. tuberregium sclerotia. Its pasting temperature was $60.16^{\circ} \mathrm{C}$ while its peak time was $5.97 \mathrm{mins}$. Pasting temperature obtained in this work was lower than pasting temperature $\left(86.70^{\circ} \mathrm{C}\right)$ and peak time $(7.90 \mathrm{~min})$ reported by Kolawole, et al. [28] for P. tuberregium flour obtained from sclerotia oven dried at $40^{\circ} \mathrm{C}$. Subroto, et al. [29] reported an increase in pasting temperature of potato starch oven dried at $40^{\circ} \mathrm{C}$ when compared with pasting temperatures of starch obtained by heat moisture treatment. This suggests that pre-treatment such as oven drying affects pasting temperature which causes molecular rearrangement of starch molecules resulting to closed packed structure of amylose and amylopectin molecules hence influencing water absorption within the amorphous and crystalline regions. Pasting temperature indicates the temperature at which viscosity begins to rise [30] and it ensures swelling, gelatinization and subsequent gel formation during processing [31]. Peak time is a measure of cooking time [32]. Low peak time is desirable to save energy required to form gels from starch. Therefore $P$. tuberregium flour obtained from air dried sclerotia has a moderate pasting temperature and peak time hence, will not consume much energy to cook.

Peak viscosity (PV) was 350.55RVU. This was in contrast to peak viscosity reported by Kolawole, et al. [28] for $P$. tuberregium flour which had a value of $101.33 \mathrm{RVU}$. The high PV reported for P. tuberregium flour obtained in our work could be due to less interaction between water molecules and amylose-amylopectin granules through hydrogen bonds. Charles, et al. [33] attributed a high peak viscosity to be caused by low levels of amylose and failure to re-associate with amylopectin and strengthen the molecular network. Peak viscosity can be affected by amylose/amylopectin content and ratios, molecular weight, intermolecular conformation and the degree of polymerization of amylose and amylopectin, amount of amylopectin branching and the presence of minor components [34].

Hot paste viscosity (HPV, i.e Trough) was 101.50RVU. This was higher than 72.62RVU reported Kolawole, et al. [28] for P. tuberregium flour. HPV is the minimum viscosity value which measures the ability of paste to withstand breakdown during cooking [16]. Breakdown viscosity (BD) obtained in this work for P. tuberregium flour from air dried sclerotia was $149.51 \mathrm{RVU}$ while Kolawole, et al. [28] reported a value of $24.52 \mathrm{RVU}$ for $P$. tuberregium flour obtained from sclerotia oven dried at $40^{\circ} \mathrm{C}$. Breakdown viscosity is a crucial factor in determining paste stability during heating and mechanical shear stress encountered during processing Arinola, et al. [35]. Adebowale, et al. [32] reported that a higher breakdown viscosity results to a reduced ability of flour to withstand heating and shear stress during cooking. Therefore, in this current study it can be deduced that air dried $P$. tuberregium flour has a low ability to withstand heating and shear stress.

Final viscosity (i.e cold paste viscosity) and set back viscosity were 391.56RVU and 290.06RVU respectively while Kolawole, et al. [28] reported values of $68.64 \mathrm{RVU}$ and $41.10 \mathrm{RVU}$ for final viscosity and set back viscosity respectively for $P$. tuberregium flour obtained from sclerotia oven dried at $40^{\circ} \mathrm{C}$. The extent to which amylose molecules join to form a strong gel after cooling affects the final viscosity Subroto, et al. [29]. Final viscosity indicates the re-association of starch granules especially amylose during cooling time after gelatinization and the formation of gel network [36]. Set back viscosity represents viscosity of starch after heating to $50^{\circ} \mathrm{C}$. The lower the set back viscosity, the higher the resistance to retrogradation [37]. High set back viscosity obtained in this study suggests that flour produced from air dried P. tuberregium sclerotia can easily retrograde while the final viscosity indicated a high re-association of starch granules during cooling time after gelatinization.

Stability ratio and set back ratio were 0.29 and 2.77 respectively. Stability ratio obtained for $P$. tuberregium flour was lower than stability ratio of wheat flour (0.53) reported by Julianti, et al. [16]. Set back ratio of $P$. tuberregium flour was higher than set back ratio of wheat flour (2.02) [16]. Stability ratio provides information on the resistance of a starch paste to viscosity breakdown as shear is applied while set back ratio is an index of starch retrogradation tendency after gelatinization $[16]$. This confirms that $P$. tuberregiumflour obtained from air dried sclerotia has low resistance to viscosity breakdown as shear is applied and a high tendency to retrograde.

Table-2. Pasting properties of Pluerotus tubberregium flour from air dried sclerotia

\begin{tabular}{l|l}
\hline Parameter & Value \\
\hline Pasting temperature $\left({ }^{\circ} \mathrm{C}\right)$ & $60.16 \pm 1.51$ \\
\hline Pasting time (min) & $5.97 \pm 0.0$ \\
\hline Peak viscosity (RVU) & $350.55 \pm 0.77$ \\
\hline Hot paste viscosity (RVU) & $101.50 \pm 2.09$ \\
\hline Breakdown viscosity (RVU) & $149.51 \pm 0.69$ \\
\hline Final viscosity (RVU) & $391.56 \pm 2.17$ \\
\hline Setback viscosity (RVU & $290.06 \pm 0.08$ \\
\hline Stability rat & $0.29 \pm 0.01$ \\
\hline Setback ratio & $2.77 \pm 0.05$
\end{tabular}

Note: Values are means \pm standard deviation.

\subsection{Functional Properties}

Results on functional properties of Pluerotus tubberregium flour from air dried sclerotia is shown in Table 3. Its bulk density $(\mathrm{BD})$ was $0.4 \mathrm{~g} / \mathrm{ml}$. This value was higher than $\mathrm{BD}$ of $0.29 \mathrm{~g} / \mathrm{ml}$ reported for Pluerotus tubberregium flour by Kolawole, et al. [28] Agaricusbisporus $(0.22 \mathrm{~g} / \mathrm{ml})$ and Pluerotus ostreatus $(0.28 \mathrm{~g} / \mathrm{ml})$ reported by Ishara, et al. [1] but lower than BD of Termitomyces heimii $(0.74 \mathrm{~g} / \mathrm{ml})$ reported by Due, et al. [38]. Bulk density is influenced by 
the structure of starch polymers and loose structure of starch polymer could result to low bulk density [39]. A low bulk density is ideal for infant meal [40]. This suggests that the bulk density obtained for flour from air dried Pluerotus tubberregium sclerotia could be suitable for the production of infant formula.

Its water absorption capacity (WAC) and oil absorption capacity (OAC) were $4.20 \mathrm{~g} / \mathrm{g}$ and $4.13 \mathrm{~g} / \mathrm{g}$ respectively. WAC observed in this work was lower than WAC reported for $A$. bisporus $(5.43 \mathrm{~g} / \mathrm{g})$ and $P$. ostreatus $(7.19 \mathrm{~g} / \mathrm{g})$ reported by Ishara, et al. [1]. Flour with a water absorption capacity greater than $125 \mathrm{ml} / 100 \mathrm{~g}$ (ie $1.25 \mathrm{~g} / \mathrm{g}$ ) points out good bakery property [41]. Therefore it is an indication that Pluerotus tuberregium flour from air dried sclerotia can be good in bakery products. As regards OAC, the value obtained in this research was higher than OAC of P. tubberregium flour $(0.22 \mathrm{ml} / \mathrm{g})$ reported by Kolawole, et al. [28]T. hemii $(125.25 \%=1.2525 \mathrm{~g} / \mathrm{g})$ Due, et al. [38] but lower than OAC A. bisporus $(548.3 \%=5.483 \mathrm{~g} / \mathrm{g})$ and $P$. ostreatus $(462.6 \%=4.626 \mathrm{~g} / \mathrm{g})[1]$. Variation in OAC of flour from different food items could be influenced by differences in non- polar side chains of proteins which bind hydrocarbon side chain of the oil through hydrophobic interactions [42]. The fewer the non-polar amino acids, the less the hydrophobic interactions with hydrocarbon chain of oil, hence resulting to low oil absorption capacity.

Emulsion activity (EA) and emulsion stability (ES) obtained in this study were $30.22 \%$ and $45.12 \%$ respectively. EA of P. tuberregium flour was lower than EA of wheat flour (43.88)[33] while its ES (45.12\%) was higher than ES of wheat flour (38.38\%) [33]. Foam capacity (FC) obtained in this study (7.27\%) was lower than FC of $T$. heimii flour (16.67\%) Due, et al. [38] pearl millet (11.30\%), quinoa flour (9\%)[43] as well as wheat flour $(12.92 \%)$ [33]. The foam stability (FS) obtained in this study (31.55\%) was lower than FS of species of P. ostreatus flour which ranged between $45.7 \%$ and $66.8 \%[44]$ but higher than FS reported for wheat flour (1.94\%)[33]. An inverse relationship exists between foam capacity and foam stability[33]. Flours with low foam capacity could form small air bubbles enclosed by a dense and more stiff protein film as such may not collapse easily hence, resulting to a higher foam stability.

Swelling capacity and swelling index for $P$. tuberregium flour in this study were $4.17 \%$ and $1.61 \%$ respectively. Mushroom flour has been reported to have low swelling capacity [45]. Similarly, Ojo, et al. [46] reported a significant decrease in swelling properties of cassava-mushroom flour blends with increased substitution of mushroom flour. The ability of starch particles to retain water and swell is based on the extent of water retention through hydrogen bonding and is controlled by its amylose content as well as its amylopectin side chains [47].

Dispersibilty index for P. tubberregium flour was $53 \%$. Dispersibilty is an index that measures how well a flour/flour blends can be rehydrated with water [21]. A high dispersibilty enhances better reconstitution of starch in water to give fine and functional paste[31]. This suggests that $P$. tuberregium flour from air dried sclerotia will rehydrate moderately in water to give a fine paste. Gelatinization temperature obtained for P. tubberregium flour in this study was $94^{\circ} \mathrm{C}$. This was quite higher than gelatinization temperatures of $S$. citritum $\left(70{ }^{\circ} \mathrm{C}\right)$ and $P$. ostreatus $\left(80{ }^{\circ} \mathrm{C}\right)$ reported byAniekemabasi, et al. [23]. Gelatinization temperature of starch is affected by botanical origin, amylose content and the structure of the amylopectin in the molecules Aniekemabasi, et al. [23]. High gelatinization temperature is associated with low amylose content and suggests thermal stability Aniekemabasi, et al. [23]. It was observed that P. tubberregium flour from air dried sclerotia had a regular amylose content which could be categorized as low Table 1 and this suggests its high gelatinization temperature.

\begin{tabular}{l|c}
\multicolumn{2}{c}{ Table-3. Functional properties of Pluerotus tubberregium flour from air dried sclerotia. } \\
\hline Parameter & Value \\
\hline Bulk density $\left(\mathrm{g} / \mathrm{cm}^{3}\right)$ & $0.40 \pm 0.00$ \\
\hline Water absorption capacity $(\mathrm{g} / \mathrm{g})$ & $4.20 \pm 0.12$ \\
\hline Oil absorption capacity $(\mathrm{g} / \mathrm{g})$ & $4.13 \pm 0.12$ \\
\hline Emulsion capacity $\%)$ & $30.22 \pm 1.62$ \\
\hline Emulsion stability $(\%)$ & $45.12 \pm 1.82$ \\
\hline Foam capacity $(\%)$ & $7.27 \pm 0.10$ \\
\hline Foam stability $(\%)$ & $31.55 \pm 1.58$ \\
\hline Swelling capacity $(\mathrm{g} / \mathrm{g})$ & $4.17 \pm 0.88$ \\
\hline Swelling index $(\mathrm{g} / \mathrm{g})$ & $1.61 \pm 0.07$ \\
\hline Dispersibility index $(\%)$ & $53.00 \pm 1.00$ \\
\hline Gelatinization temperature $\left({ }^{\circ} \mathrm{C}\right)$ & $94.00 \pm 0.00$ \\
\hline Note: Values are means \pm standard deviation.
\end{tabular}

\section{Conclusion}

It is concluded that flour from air dried Pluerotus tubberregium sclerotia has a regular (ie low) and high resistant starch based on values for its amylose and resistant starch contents. Therefore, it can be incorporated in food formulations for nutritional purposes where its resistant starch can function as a prebiotic. The pasting properties indicated that the flour can retrograde based on its set back viscosity and set back ratios and a low tendency to withstand shear stress based on its breakdown viscosity and stability ratio. Its functional properties indicated that it can be used in food formulations where low bulk density is desirable such as in weaning foods and will be useful as a good thickener and in low fat foods based on its water and oil absorption capacities. However, there is need for technological modification to improve its pasting properties so as to generate flour with a high stability ratio and a low set back ratio and so withstand retrogradation and with improved resistance to shear stress.

\section{References}

[1] J. R. Ishara, D. N. Sila, G. M. Kenji, and A. K. Buzera, "Nutritional and functional properties of mushroom (Agaricus bisporus \& Pleurotus ostreatus) and their blends with maize flour," American Journal of Food Science and Technology, vol. 6, pp. 33-41, Available at: https://doi.org/10.12691/ajfst-6-1-6.

[2] I. I. Ijeh, I. A. Okwujiako, P. C. Nwosu, and H. I. Nnodim, "Phytochemical composition of Pluerotus tubberregium and effect of its dietary incorporation on body organ weights and serum triglycerides in albino mice," Journal of Medicinal Plants Research, vol. 3 , pp. 939-943. 
F. C. Thorn, K. A. Greg, C. U. Malcavo, A. O. Jean-Marc, E. T. Reddy, A. E. Vilgalys, and R. C. Rytas, "Phylogenetic analysis and distribution of nematophagy support, a monophyletic pleurotaceae within Polyphyletic Pleurotoid-lentinoid fungi," Mycolagia, vol. 92, pp. 241-252.

[4] S. Oranusi, C. Ndukwe, and W. Braide, "Production of pleurotus tuber-regium (Fr.) Sing Agar, chemical composition and microflora associated with sclerotium," International Journal of Current Microbiology and Applied Sciences, vol. 3, pp. 115-126.

[5] R. N. Tharanathan, "Starch value addition by modification," Critical Reviews in Food Science and Nutrition, vol. 45, pp. 371-384.

[6] G. O. Olatunde, L. K. Arogundade, and O. I. Orija, "Chemical, functional and pasting properties of banana and plantain starches modified by pre-gelatinization, oxidation and acetylation," Cogent Food $\&^{\circ}$ Agriculture, vol. 3, p. 1283079, Available at: doi:1080/23311932.2017.1283079.

B. O. Otegbayo, J. O. Aina, and R. Asiedu, "Effect of storage on the pasting characteristics of yam starches," in Proceedings of 30th Annual Conference of Nigerian Institute of Food Science and Technology, 2006, pp. 187-188.

[8] S. A. Sofi, A. Anjum, and J. Awsi, "Resistant starch as functional ingredient: A review," International Journal of Food Science and Nutrition, vol. 2, pp. 195-199.

[9] R. Baixauli, A. Salvador, S. Martinez-Cervera, and S. Fiszman, "Distinctive sensory features introduced by resistant starch in baked products," LWT-Food Science and Technology, vol. 41, pp. 1927-1933, Available at: https://doi.org/10.1016/j.lwt.2008.01.012.

[10] H. J. Wlllets and S. Bullock, "Development biology of sclerotia," Mycology Research, vol. 96, pp. 801-816.

[11] B. V. Mccleary, T. S. Gibson, and D. C. Mugford, "Measurement of total starch in cereal products by amyloglucosidase- $\alpha$-amylase method: Collaborative study," Journal of AOAC International, vol. 80, pp. 571-579.

[12] K. Mohana, A. Urooj, and N. N. Prasad, "Effect of storage on resistant starch and amylose content of cereal-pulse based ready-toeat commercial products," Food Chemistry, vol. 102, pp. 1425-1430.

[13] G. Juan, A. Luis, and B. David, "Isolation and molecular characterization of Makal (Xanthosoma yucatanensis) starch," Starch, vol. 58, pp. 300-307, Available at: https://doi.org/10.1002/star.200500451.

[14] I. Goñi, L. Garcia-Diz, E. Mañas, and F. Saura-Calixto, "Analysis of resistant starch: A method for foods and food products," Food Chemistry, vol. 56, pp. 445-449.

[15] AACC, Approved Methods of the American Association of Cereal Chemists, 10th ed. Paul Minn, USA: Methods of Analysis 54-21 and 1010B" American Association of Cereal Chemists, St, 2000.

[16] E. Julianti, H. Rusmarilin, and E. Yusraini, "Functional and rheological properties of composite flour from sweet potato, maize, soybean and xanthan gum," Journal of the Saudi Society of Agricultural Sciences, vol. 16, pp. 171-177, Available at: https://doi.org/10.1016/j.jssas.2015.05.005.

[17] O. Onabanjo and D. Ighere, "Nutritional, functional and sensory properties of biscuit produced from wheat-sweet potato composite," Journal of Food Technology Research, vol. 1, pp. 111-121, Available at: https://doi.org/10.18488/journal.58/2014.1.2/58.2.111.121.

[18] K. Yasumatsu, K. Sawada, S. Moritaka, M. Misaki, J. Toda, T. Wada, and K. Ishii, "Whipping and emulsifying properties of soybean products," Agricultural and Biological Chemistry, vol. 36, pp. 719-727, Available at: https://doi.org/10.1271/bbb1961.36.719.

[19] K. Narayana and M. Narasinga Rao, "Functional properties of raw and heat processed winged bean (Psophocarpus tetragonolobus) flour," Journal of Food Science, vol. 47, pp. 1534-1538.

[20] U. Ukpabi and C. Ndimele, "Evaluation of the quality of gari produced in Imo State," Nigerian Food Journal, vol. 8, pp. 105-1 10.

[21] K. D. Kulkarni, D. Kulkarni, and U. Ingle, "Sorghum malt-based weaning food formulations: preparation, functional properties, and nutritive value," Food and Nutrition Bulletin, vol. 13, pp. 1-7.

[22] B. G. Shinde, "Isolation and characterization of starch horse grain." Rahuri (India)," Unpublished M.Sc Thesis, Mahatma Phule Krishi Vidyapeeth, 2001.

[23] U. I. Aniekemabasi, B. N. Ita, and B. A. Uwemobong, "Physicochemical properties of starches from scleroderma citrinum and pleurotus ostreatus," The Pharmaceutical and Chemical Journal, vol. 5, pp. 191-195.

[24] A. I. Falodun, H. N. Ayo-Omogie, and O. O. Awolu, "'Effect of different drying techniques on the resistant starch, bioactive components, physicochemical and pasting properties of cadaba banana flour," Acta Universitatis Cibiniensis. Series E: Food Technology, vol. 23 , pp. 35-42.

[25] N. O. Alobi, E. A. Sunday, T. O. Magu, G. O. Oloko, and B. E. Nyong, "Analysis of starch from non-edible root and tubers as sources of raw materials for the synthesis of biodegradable starch plastic," Journal of Basic and Applied Research, vol. 3, pp. $27-32$.

[26] N. Morante, H. Ceballos, T. Sánchez, A. Rolland-Sabaté, F. Calle, C. Hershey, O. Gibert, and D. Dufour, "Discovery of new spontaneous sources of amylose-free cassava starch and analysis of their structure and techno-functional properties," Food Hydrocolloids, vol. 56, pp. 383-395, Available at: https://doi.org/10.1016/j.foodhyd.2015.12.025

[27] S. M. Chisenga, T. S. Workneh, G. Bultosa, and M. Laing, "Characterization of physicochemical properties of starches from improved cassava varieties grown in Zambia," AIMS Agric. Food, vol. 4, pp. 939-966.

[28] F. Kolawole, B. Akinwande, and B. Ade-Omowaye, "Chemical composition, colour, functional and pasting properties of orangefleshed sweet potato, Pleurotus tuberregium sclerotium and their flour blends," Annals Food Science and Technology, vol. 19, pp. 423432 .

[29] E. Subroto, R. Indiarto, H. Marta, and S. Shalihah, "Effect of heat moisture treatment on functional and pasting properties of potato," Food Research, vol. 3, pp. 469-476.

[30] X. Liang and J. King, "Pasting and crystalline property differences of commercial and isolated rice starch with added amino acids," Journal of Food Science, vol. 68, pp. 832-838.

[31] J. Eke-Ejiofor, "Physico-chemical and pasting properties of starches from cassava, sweet potato and three leaf yam and their application in salad cream production," International Journal of Biotechnology and Food Science, vol. 3, pp. 23-30.

[32] A. Adebowale, L. Sanni, and S. Awonorin, "Effect of texture modifiers on the physicochemical and sensory properties of dried fufu," Food Science and Technology International, vol. 11, pp. 373-382, Available at: https://doi.org/10.1177/1082013205058531.

[33] A. L. Charles, Y. H. Chang, W. C. Ko, K. Sriroth, and T. C. Huang, "Influence of amylopectin structure and amylose content on the gelling properties of five cultivars of cassava starches," Journal of Agricultural and Food Chemistry, vol. 53, pp. 2717-2725, Available at: https://doi.org/10.1021/jfo48376+.

[34] E. Mélo, T. Stamford, M. Silva, N. Krieger, and N. Stamford, "Functional properties of yam bean (Pachyrhizus erosus) starch," Bioresource Technology, vol. 89, pp. 103-106.

[35] S. Arinola, E. Ogunbusola, and S. Adebayo, "Effect of drying methods on the chemical, pasting and functional properties of unripe plantain (Musa paradisiaca) flour," Current Journal of Applied Science and Technology, vol. 14, pp. 1-7.

[36] F. E. Ortega-Ojeda, H. Larsson, and A.-C. Eliasson, "Gel formation in mixtures of high amylopectin potato starch and potato starch," Carbohydrate Polymers, vol. 56, pp. 505-514.

[37] L. Sanni, S. Kosoko, A. Adebowale, and R. Adeoye, "The influence of palm oil and chemical modification on the pasting and sensory properties of fufu flour," International Journal of Food Properties, vol. 7, pp. 229-237.

[38] E. A. Due, D. M. Koffi, and Y. D. Digbeu, "Physicochemical and functional properties of flour from wild edible mushroom Termitomyces heimii Natarajan harvested in Cote d'Ivoire," Turkish Journal of Agriculture-Food Science and Technology, vol. 4, pp. $651-655$.

[39] O. Malomo, O. Ogunmoyela, O. Adekoyeni, O. Jimoh, S. Oluwajoba, and M. Sobanwa, "Rheological and functional properties of soy-poundo yam flour," International Journal of Food Science and Nutrition Engineering, vol. 2, pp. 101-107.

[40] P. Thakur, V. Pawar, and D. Shere, "Material balance, proximate and functional analysis of green banana flour prepared by cabinet drying method," Food Science Research Journal, vol. 7, pp. 190-194, Available at: https://doi.org/10.15740/has/fsrj/7.2/190-194.

[41] S. Y. Giami and D. A. Alu, "Changes in composition and certain functional properties of ripening plantain (Musa spp., AAB group) pulp," Food Chemistry, vol. 50, pp. 137-140, Available at: https://doi.org/10.1016/0308-8146(94)90110-4.

[42] S. Jitngarmkusol, J. Hongsuwankul, and K. Tananuwong, "Chemical compositions, functional properties, and microstructure of defatted macadamia flours," Food Chemistry, vol. 110, pp. 23-30, Available at: https://doi.org/10.1016/j.foodchem.2008.01.050. 
[43] H. O. Oshodi, MO Oladimeji, AA, "Chemical composition, nutritionally valuable minerals and functional properties of benniseed (Sesamum radiatum), pearl millet (Pennisetum typhoides) and quinoa (Chenopodium quinoa) flours," International Journal of Food Sciences and Nutrition, vol. 50, pp. 325-331.

[44] A. Cruz-Solono, R. Villanueva-Arce, M. B. Garin-Aguilar, H. Leal-Lara, and G. V.-d. Toto, "Functional properties of flours and protein concentrates of three strains of the edible mushroom pluerotus ostreatus," Journal of Food Science and Technology, vol. 55, pp. 3892-3901.

[45] A. Ajala and T. Taiwo, "Study on supplementation of 'ogi'with oyster mushroom flour (Pleurotus ostreatus)," J Nutr Health Food Eng, vol. 8, pp. 287-291.

[46] M. Ojo, C. Ariahu, and E. Chinma, "Proximate, functional and pasting properties of cassava starch and mushroom (Pleurotus Pulmonarius) flour blends," American Journal of Food Science and Technology, vol. 5, pp. 11-18.

[47] H. Tang, T. Mitsunaga, and Y. Kawamura, "Relationship between functionality and structure in barley starches," Carbohydrate Polymers, vol. 57, pp. 145-152. 